\title{
NUMERICAL STUDY OF ARGON EFFECT ON NITROGEN SEPARATION FROM AIR BY PRESSURE SWING ADSORPTION
}

\author{
Abdulbasit Hassan Mahdi ${ }^{1}$, Suhaib Shwish Salih ${ }^{1 *}$, Heba Sa’ady Ayuob ${ }^{1}$, \\ AND TUSHAR GHOSH ${ }^{2}$ \\ ${ }^{1}$ Tikrit University, College of Engineering, Department of Chemical Engineering, \\ Salahaldin, Iraq. \\ ${ }^{2}$ Department of Nuclear Science \& Engineering Institute, \\ University of Missouri-Columbia, Missouri, United States. \\ "Corresponding author: sss43b@mail.missouri.edu
}

(Received: 19 $9^{\text {th }}$ June 2019; Accepted: $30^{\text {th }}$ September 2019; Published on-line: $20^{\text {th }}$ January 2020)

\begin{abstract}
A mathematical model was used to design four modes of two-bed pressure swing adsorption (PSA) process to investigate argon presence in the feed mixture. The effect of operating parameters such as cycle time, pressure equalization, adsorption pressure, and purging flow rate was investigated. The model was validated with experimental data of nitrogen separation from the air by a single bed adsorber on carbon molecular sieve (CMS). A good agreement with experimental data is obtained. In the PSA process, higher purity of nitrogen $(99.7 \%)$ was detected by mode 4 when the feed mixture was free of argon $\left(\mathrm{O}_{2}: 21 \%, \mathrm{~N}_{2}: 79 \%\right)$. While the nitrogen purity was only $98.0 \%$ in the state of argon presence in the feed mixture $\left(\mathrm{O}_{2}: 21 \%, \mathrm{~N}_{2}: 78 \%, \operatorname{Ar}: 1 \%\right)$. The results showed that the cycle time had insignificant effect whereas the pressure equalization and purging at low vacuum pressure had a significant effect on the process performance.
\end{abstract}

ABSTRAK: Model matematik digunakan bagi membina empat mod terdiri daripada tekanan dua-turus proses penyerapan buai (PSA) bagi menyiasat kehadiran argon dalam campuran pakan. Kesan parameter beroperasi seperti masa kitaran, penyamaan tekanan, tekanan penyerapan, dan kadar aliran penyingkiran disiasat. Model matematik tersebut disiasat melalui data eksperimen pemisahan nitrogen dari udara melalui penyerapan turus tunggal pada penapis molekular karbon (CMS). Data eksperimen yang bagus diperoleh. Dalam proses PSA, mod keempat menghasilkan ketulenan nitrogen $(99.7 \%)$ lebih tinggi apabila campuran pakan bebas argon $\left(\mathrm{O}_{2}: 21 \%, \mathrm{~N}_{2}: 79 \%\right)$. Sementara itu, ketulenan nitrogen hanya $98.0 \%$ apabila terdapat kehadiran argon dalam campuran pakan $\left(\mathrm{O}_{2}\right.$ : $21 \%, \mathrm{~N}_{2}: 78 \%$, Ar: 1\%). Kajian menunjukkan masa kitaran memberi kesan tidak signifikan sementara penyamaan tekanan dan penyingkiran pada tekanan vakum rendah mempunyai kesan signifikan terhadap prestasi proses.

KEYWORDS: nitrogen separation; PSA; argon; model simulation

\section{INTRODUCTION}

Gaseous nitrogen is used extensively in many industries such as vessel inerting applications, electronics, metals, and food industries due to its inert properties [1]. A variety of separation processes are used to produce commercial nitrogen such as cryogenic distillation, adsorption separation, and membrane separation processes. PSA is one of the most important process in the field of gas separation [2-4]. A carbon molecular sieve 
(CMS) is used as an adsorbent for nitrogen separation from air due to the difference in the kinetic adsorption of oxygen and nitrogen [5-7]. Since oxygen is faster than nitrogen to diffuse into the CMS, a kinetic selectivity is created, which allows reaching nitrogen purities as high as $99.999 \%$. The demand for high nitrogen purity, over $99 \%$, in a low and medium amount in the industrial sector has urged a lot of companies to produce nitrogen from atmospheric air by PSA process [8]. Zeolite X-type and perovskite-type ceramic were used as adsorbents instead of the CMS sieve for nitrogen separation from air at high pressure [9-12].

In the last decades, the PSA process was investigated experimentally and theoretically in many studies $[13,14]$. For instance, a simple linear driving force (LDF) model was created to simulate a single bed PSA process for nitrogen separation from the air on CMS. The feed mixture was assumed to be $\left(\mathrm{O}_{2}: 21 \%\right.$, and $\left.\mathrm{N}_{2}: 79 \%\right)$ [15]. The effect of bed length and pressurizing rate on the single bed PSA performance was studied carefully. The higher performance of the process was observed with a bed length over $1.3 \mathrm{~m}$. The effect of the adsorption/desorption rate constants of oxygen on the nitrogen separation was evaluated through a simulation process and found that the purity varied significantly with cycle time $[8,16]$. Operating parameters such as feed flow, purge flow, cycle time, adsorption pressure, and bed length on the PSA process performance was studied experimentally and theoretically [17]. Higher purity of nitrogen was observed at short adsorption time. No significant effect of adsorption pressure over 4 bar on the process performance was observed. About $97.6 \%$ of nitrogen purity was detected using atmospheric air as a feed $[2,3]$. The purity was improved from $96 \%$ to over $99 \%$ by adding a deoxo reactor to the PSA process. The feed mixture only consisted of oxygen and nitrogen [18].

Many previous studies assume that the feed mixture only consists of $\mathrm{O}_{2}$ and $\mathrm{N}_{2}$, but real air consists of argon as well. So, the main objective of this study is to investigate the effect of argon presence in the feed mixture and operating parameters on the nitrogen purity. A mathematical model is introduced to study the nitrogen separation from the air by single bed adsorber on a CMS sieve. Then, it is employed to design four configurations of the two-bed PSA process to deeply investigate the process and compare the four modes.

\section{MODELING AND SIMULATION}

A theoretical study is employed to investigate the nitrogen separation from atmospheric air by PSA process. The numerical study was applied to the following processes:

a) Single bed adsorber to study the breakthrough time.

b) Two-bed PSA process with the four different configurations as shown in Table 4.

The first design of the PSA process is represented by the Skarstrom cycle, which involved four steps: pressurizing, producing, depressurizing, and purging steps. Different modifiers are added such as purging by vacuum pump, pressure equalization, and product pressurizing, to improve the performance of the PSA process.

The numerical study of the PSA process was carried out using a simulation program. Finite difference method (FDM) is employed, and axial dimension is discretized into 50 nodes. The purity of oxygen or nitrogen is used as an indication of the process performance. The following assumptions are considered in the numerical study:

1- Feed mixture assumed to be $\left(\mathrm{O}_{2}: 21 \%, \mathrm{~N}_{2}: 78 \%\right.$, Ar: $1 \%$, and $\left.\mathrm{O}_{2}: 21 \%, \mathrm{~N}_{2}: 79 \%\right)$. 
2- Ideal gas law is applied.

3- Isothermal system.

4- The flow pattern is described by the axial dispersion plug flow model.

5- Radial concentration is neglected.

6- Mass Transfer transport is described by a linear driving force (LDF).

7- Adsorption equilibrium is fitted with the Langmuir equation.

8- Pressure drop along the bed is represented by the Darcy equation.

Overall mass balance:

$$
-D_{L} \frac{\partial^{2} c_{i}}{\partial z^{2}}+\frac{\partial C}{\partial t}+\frac{\partial(u C)}{\partial t}+\sum_{i=1}^{n} \rho p\left(\frac{1-\varepsilon}{\varepsilon}\right) \frac{\overline{\partial q}}{\partial t}=0
$$

Component (i) mass balance:

$$
-D_{L} \frac{\partial^{2} c_{i}}{\partial z^{2}}+\frac{\partial\left(u c_{i}\right)}{\partial z}+\frac{\partial c_{i}}{\partial t}+\rho_{\mathrm{P}}\left(\frac{1-\varepsilon}{\varepsilon}\right) \frac{\overline{\partial q}}{\partial t}=0
$$

Boundary conditions of each step of the PSA process are presented in Table 1. The boundary conditions of well-known Danckwerts are applied [19]. The adsorption isotherm and adsorption rate parameters of $\mathrm{N}_{2}, \mathrm{O}_{2}$, and Ar on CMS are presented in Table 2. The operating parameters of the single bed adsorber are presented in Table 3. The operation parameters of other modes of PSA process are presented in Table 4.

\begin{tabular}{|c|c|c|}
\hline Cycle step & Concentration $\left(c_{i}\right)$ & Velocity (u) \\
\hline $\begin{array}{l}\text { Pressurizing } \\
\quad \text { (Pre) }\end{array}$ & $\begin{array}{c}-\left.\mathrm{D}_{\mathrm{L}}\left(\partial \mathrm{c}_{\mathrm{i}} / \partial \mathrm{z}\right)\right|_{\mathrm{z}=0}=\mathrm{u}\left(\left.\mathrm{c}_{\mathrm{i}}\right|_{\mathrm{z}=0-}-\left.\mathrm{c}_{\mathrm{i}}\right|_{\mathrm{z}=0+}\right) \\
\left.(\partial \mathrm{ci} / \partial \mathrm{z})\right|_{\mathrm{z}=\mathrm{L}}=0\end{array}$ & $\begin{array}{c}\left.\mathrm{u}\right|_{\mathrm{z}=0}=\mathrm{u}_{\text {feed }} \\
\left.\mathrm{u}\right|_{\mathrm{z}=\mathrm{L}}=0\end{array}$ \\
\hline $\begin{array}{l}\text { Adsorption } \\
\text { (Ads) }\end{array}$ & $\begin{array}{c}-\left.\mathrm{D}_{\mathrm{L}}\left(\partial \mathrm{c}_{\mathrm{i}} / \partial \mathrm{z}\right)\right|_{\mathrm{z}=0}=\mathrm{u}\left(\left.\mathrm{c}_{\mathrm{i}}\right|_{\mathrm{z}=0-}-\left.\mathrm{c}_{\mathrm{i}}\right|_{\mathrm{z}=0+}\right) \\
\left.\left(\partial \mathrm{c}_{\mathrm{i}} / \partial \mathrm{z}\right)\right|_{\mathrm{z}=\mathrm{L}}=0\end{array}$ & $\left.\mathrm{u}\right|_{\mathrm{z}=0}=\mathrm{u}_{\text {feed }}$ \\
\hline $\begin{array}{l}\text { Depressure- } \\
\text { Equalization (DepEqu) }\end{array}$ & $\begin{array}{l}-\left.\mathrm{D}_{\mathrm{L}}\left(\partial \mathrm{c}_{\mathrm{i}} / \partial \mathrm{z}\right)\right|_{\mathrm{z}=0}=0 \\
-\left.\mathrm{D}_{\mathrm{L}}\left(\partial \mathrm{c}_{\mathrm{i}} / \partial \mathrm{z}\right)\right|_{\mathrm{z}=\mathrm{L}}=0\end{array}$ & $\left.\mathrm{u}\right|_{\mathrm{z}=0}=0$ \\
\hline $\begin{array}{l}\text { Depressurizing } \\
\quad \text { (Dep) }\end{array}$ & $\begin{array}{c}\left.\mathrm{D}_{\mathrm{L}}\left(\partial \mathrm{c}_{\mathrm{i}} / \partial \mathrm{z}\right)\right|_{\mathrm{z}=0}=0 \\
-\left.\mathrm{D}_{\mathrm{L}}\left(\partial \mathrm{c}_{\mathrm{i}} / \partial \mathrm{z}\right)\right|_{\mathrm{z}=\mathrm{L}}=0\end{array}$ & $\left.\mathrm{u}\right|_{\mathrm{z}=\mathrm{L}}=0$ \\
\hline $\begin{array}{l}\text { Purging } \\
\text { (Pur) }\end{array}$ & $\begin{array}{c}-\left.\mathrm{D}_{\mathrm{L}}\left(\partial \mathrm{c}_{\mathrm{i}} / \partial \mathrm{z}\right)\right|_{\mathrm{z}=\mathrm{L}}=\mathrm{u}\left(\left.\mathrm{c}_{\mathrm{i}}\right|_{\mathrm{z}=\mathrm{L}+}-\left.\mathrm{c}_{\mathrm{i}}\right|_{\mathrm{z}=\mathrm{L}-}\right) \\
-\left.\mathrm{D}_{\mathrm{L}}(\partial \mathrm{ci} / \partial \mathrm{z})\right|_{\mathrm{z}=0}=0\end{array}$ & $\left.\mathrm{u}\right|_{\mathrm{z}=\mathrm{L}}=\mathrm{u}_{\text {purge }}$ \\
\hline $\begin{array}{l}\text { Pressure-Equalization } \\
\text { (PreEqu) }\end{array}$ & $\begin{array}{c}-\left.\mathrm{D}_{\mathrm{L}}\left(\partial \mathrm{c}_{\mathrm{i}} / \partial \mathrm{z}\right)\right|_{\mathrm{z}=0}=\mathrm{u}\left(\left.\mathrm{c}_{\mathrm{i}}\right|_{\mathrm{z}=0-}-\left.\mathrm{c}_{\mathrm{i}}\right|_{\mathrm{z}=0+}\right) \\
\left.\left(\partial \mathrm{c}_{\mathrm{i}} / \partial \mathrm{z}\right)\right|_{\mathrm{z}=\mathrm{L}}=0\end{array}$ & $\left.\mathrm{u}\right|_{\mathrm{z}=0}=0$ \\
\hline
\end{tabular}

Table 1: Applied boundary conditions in the simulation process.

Initial conditions:

$\mathrm{c}_{\mathrm{i}}(\mathrm{z}, 0)=c_{0} ; \quad q_{i}(\mathrm{z}, 0)=q_{i}^{*}$

Ideal gas law:

$$
\frac{P}{R T}=\sum_{i=1}^{n} c_{i}
$$


The adsorption rate is described by the LDF equation with concentration-dependent diffusivity:

$$
\begin{gathered}
\frac{\partial \bar{q}_{i}}{\partial t}=\omega_{i}\left(q_{i}^{*}-\bar{q}_{l}\right), \quad \omega_{i}=\frac{15 D_{e i}}{r_{c}^{2}} \\
\text { Where: }{ }^{D_{e i}} /_{r_{c}^{2}}=C P_{r}^{0.5}\left(1+B_{i} P_{i)}{ }^{2}\right.
\end{gathered}
$$

The LDF coefficient $\left(\omega_{i}\right)$ has been estimated from the fitting between the mathematical model and experimental data of single bed adsorber from the literature survey. The predicted values are presented in Table 2.

The adsorption isotherm for multi-components (oxygen, nitrogen, and argon) are predicted by the Langmuir equation to the $n$-component mixture:

$$
q_{i}=\frac{q_{m i} B_{i} P_{i}}{1+\sum_{j=1}^{n} B_{j} P_{j}}
$$

Where: $q_{m i}=k_{1}+k_{2} * T$, and $B=k_{3} \exp \left(\frac{k_{4}}{T}\right)$,

Table 2: Adsorption equilibrium and adsorption rate parameter [20].

\begin{tabular}{lccc}
\hline \multicolumn{1}{c}{ Parameters } & $\mathbf{O}_{2}$ & $\mathbf{N}_{\mathbf{2}}$ & $\mathbf{A r}$ \\
\hline $\mathrm{K}_{1} * 10^{3}(\mathrm{~mol} / \mathrm{g})$ & $5.817 \times 10^{-3}$ & $1.130 \times 10^{-2}$ & $9.556 \times 10^{-3}$ \\
$\mathrm{~K}_{2} * 10^{5}(\mathrm{~mol} / \mathrm{g})$ & $-7.512 \times 10^{-6}$ & $-2.80 \times 10^{-5}$ & $-2.101 \times 10^{-5}$ \\
$\mathrm{~K}_{3} * 10^{5}(1 / \mathrm{Kpa})$ & $7.984 \times 10^{-6}$ & $30.89 \times 10^{-5}$ & $6.566 \times 10^{-5}$ \\
$\mathrm{~K}_{4}(\mathrm{k})$ & 1444 & 359.7 & 773.8 \\
$\omega i\left(s^{-1}\right)$ & 0.248 & 0.001 & 0.0071 \\
\hline
\end{tabular}

Darcy's equation used to predict pressure drop:

$$
-\frac{d P}{d z}=\frac{180 \mu(1-\epsilon)^{2}}{D_{p}^{2} \epsilon^{2}} u
$$

Where $: u$ is the superficial gas velocity.

Table 3: Adsorbent and common parameters were used in the single bed process.

\begin{tabular}{lc}
\hline Adsorbent & CMS \\
\hline Type & Pellet \\
Pellet density $\rho_{P}\left(\mathrm{~kg} / \mathrm{m}^{3}\right)$ & 800 \\
Bed voidage $(\varepsilon)$ & 0.30 \\
\hline Adsorption bed & \\
\hline Length $(\mathrm{m})$ & 1 \\
Diameter $(\mathrm{m})$ & 0.0254 \\
Ambient temperature $\left({ }^{\circ} \mathrm{C}\right)$ & 25 \\
Adsorption pressure $(\mathrm{bar})$ & 7 \\
Product flow rate $($ liter $/ \mathrm{min})$ & 1 \\
\hline
\end{tabular}


The performance of the PSA process is indicated by the purity and recovery of nitrogen according to the following equations:

$$
\begin{gathered}
\begin{array}{c}
\text { amount of } N_{2} \text { produced during } \\
\text { Purity }\left(N_{2} \%\right)=\frac{1}{\text { amount of total product produced during }} \\
\text { adsorption step in the product end }
\end{array} \\
\text { Recovery }\left(N_{2} \%\right)=\frac{\text { adsorption step in the product end } N_{2} \text { produced during }}{\text { amount of } N_{2} \text { fed during pressurizing, }} \\
\text { and adsorption steps in the feed end }
\end{gathered}
$$

\begin{tabular}{|c|c|c|c|c|c|}
\hline $\begin{array}{l}\text { The PSA } \\
\text { Modes }\end{array}$ & $\begin{array}{l}\text { Pressure } \\
\text { (bar) }\end{array}$ & $\begin{array}{c}\text { Product } \\
\text { flowrate } \\
\text { (liter/min) }\end{array}$ & $\begin{array}{c}\text { Purge } \\
\text { flowrate } \\
\text { (liter/min) }\end{array}$ & $\begin{array}{c}\text { Vacuum } \\
\text { purging } \\
\text { (bar) }\end{array}$ & Cycle step time (sec) \\
\hline & & & & & Pre - Ads - Dep - Pur \\
\hline $\begin{array}{l}\text { 2-bed 4-step } \\
\text { (mode } 1)\end{array}$ & $2-9$ & $0.1-5$ & $1-6$ & No & $\begin{array}{l}5-20-5-20 \\
5-30-5-30 \\
5-40-5-40 \\
5-50-5-50 \\
5-60-5-60 \\
5-70-5-70 \\
5-80-5-80\end{array}$ \\
\hline 2-bed 4-step & & & & & Pre - Ads - Dep - VacPur \\
\hline $\begin{array}{l}\text { vacuum } \\
\text { purging } \\
\text { (mode } 2 \text { ) }\end{array}$ & 7 & $0.1-1$ & $1-3$ & Yes & $5-80-5-80$ \\
\hline \multirow{2}{*}{$\begin{array}{l}\text { 2-bed 6-step } \\
\text { with } \\
\text { equalization } \\
\text { pressure } \\
\text { (mode 3) }\end{array}$} & \multirow[b]{2}{*}{7} & \multirow[b]{2}{*}{$0.1-1$} & \multirow[b]{2}{*}{$1-6$} & \multirow[b]{2}{*}{ No } & Pre - Ads - DepEq - Dep - Pur - PreEq \\
\hline & & & & & $5-80-5-5-80-5$ \\
\hline \multirow[b]{2}{*}{$\begin{array}{l}\text { 2-bed 6-step } \\
\text { with } \\
\text { equalization } \\
\text { pressure and } \\
\text { vacuum } \\
\text { purging } \\
\text { (mode 4) }\end{array}$} & & \multirow[b]{2}{*}{$0.1-1$} & \multirow[b]{2}{*}{$1-3$} & \multirow[b]{2}{*}{ Yes } & Pre - Ads - DepEq - Dep - VacPur - PreEq \\
\hline & & & & & $\begin{array}{l}5-20-5-5-20-5 \\
5-30-5-5-30-5 \\
5-40-5-5-40-5 \\
5-50-5-5-50-5 \\
5-60-5-5-60-5 \\
5-70-5-5-70-5 \\
5-80-5-5-80-5 \\
5-90-5-5-90-5 \\
5-100-5-5-100-5\end{array}$ \\
\hline
\end{tabular}

Table 4: Operated conditions of the four modes of the PSA process.

\section{RESULTS AND DISCUSSION}

\subsection{Single Bed Adsorber}

The breakthrough curve of oxygen at the product end of the single bed adsorber for nitrogen separation from the air on CMS is shown in Fig. 1. The effluent flow rate is 1 
liter/min. The breakthrough time occurred at $100 \mathrm{~s}$. Thereby, the oxygen purity gradually increased until it reached a stable purity of about $20 \%$. The mass transfer zone (MTZ) is very wide due to the effect of axial dispersion during the pressurizing and producing steps. The predicted results are in good agreement with experimental data obtained by AbdelRahman [3].

Figure 2 represents the effect of product pressurizing pressure on the breakthrough time and the amount of nitrogen produced. A little improvement in the breakthrough time and in the amount of nitrogen produced was noticed. That is because the adsorption isotherm of oxygen and nitrogen are closer to each other on the CMS at equilibrium state. So increasing in the product pressurizing pressure leads to increase in the partial pressure of nitrogen in the bed and the most porosities of the adsorbent (CMS) are filled by nitrogen. Therefore, little increases in the breakthrough time may be attributed to increases in adsorbent capacity with pressure and decreased axial dispersion effects.

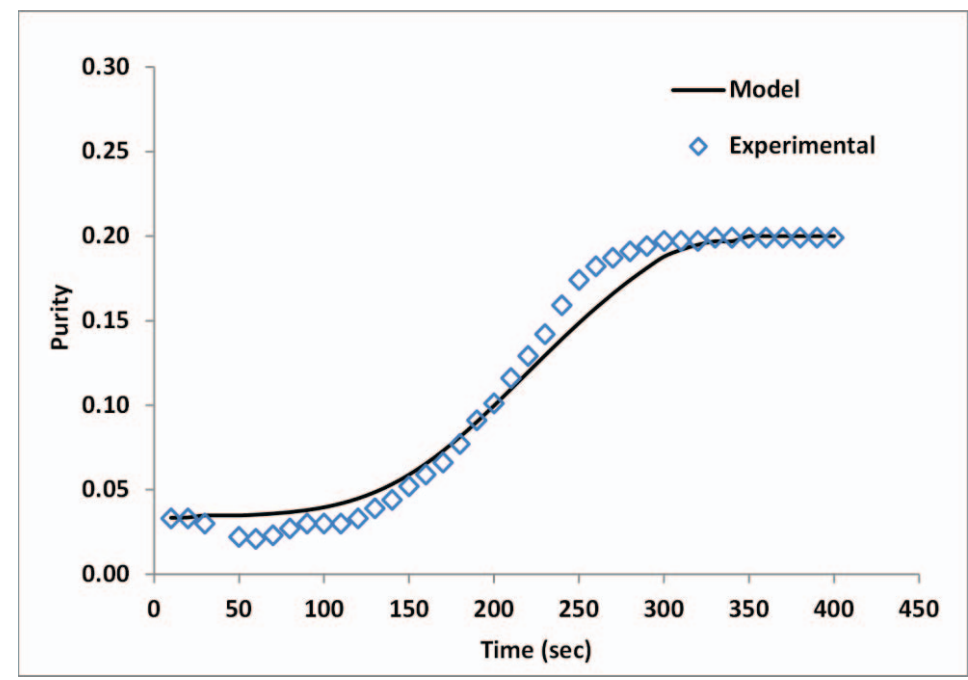

Fig. 1: Fitting between the predicted results and experimental data of oxygen breakthrough curve in the product end of single bed adsorber.

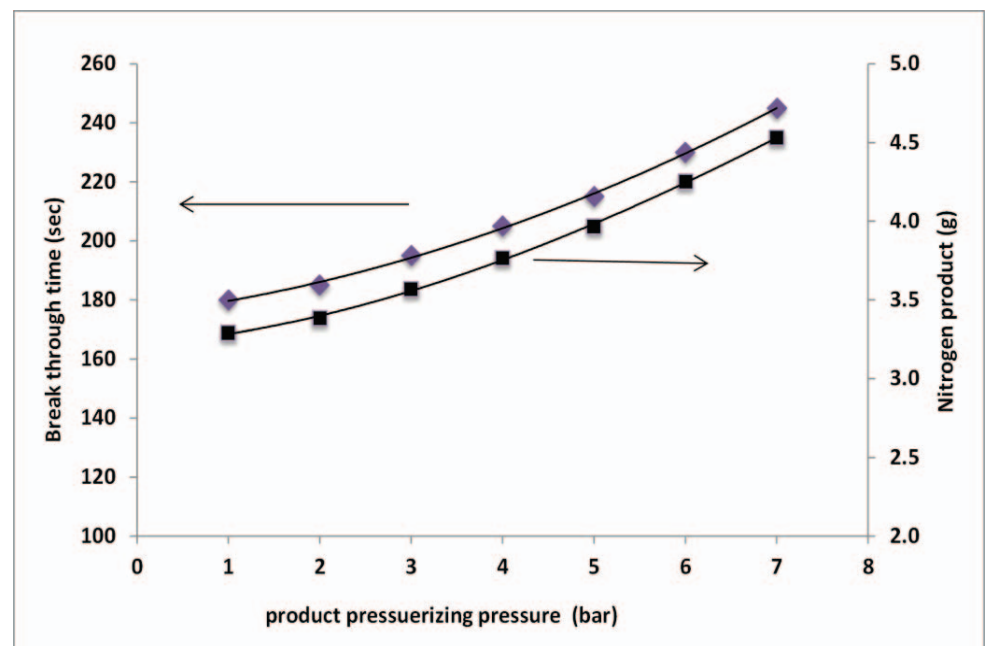

Fig. 2: Effect of product pressurizing pressure on the breakthrough time and amount of produced nitrogen in single bed adsorber. 


\subsection{Two Bed PSA Process}

\subsubsection{Effect of the Ternary Feed Mixture}

Figure 3 represents the effect of the argon presence in the feed mixture on the performance of the 2-bed 6-step PSA process (mode 3) at 7 bar pressure, 80 s adsorption time, 1-4 liter/min purge flow rate, and 0.1 liter/min product flow rate. Higher purity of nitrogen, over $99 \%$ is observed in the state of a binary feed mixture $\left(\mathrm{O}_{2} / \mathrm{N}_{2}\right)$ than a ternary feed mixture $\left(\mathrm{O}_{2} / \mathrm{N}_{2} / \mathrm{Ar}\right)$, where the maximum purity was about $95 \%$. According to the LDF coefficient values, oxygen diffuses faster than nitrogen and argon through the CMS porosity, therefore the purity of nitrogen in the product end could not be higher than the purity of the PSA process with the binary feed mixture. Most studies obtained high purity of nitrogen, over $99 \%$ when they handled a binary feed mixture.

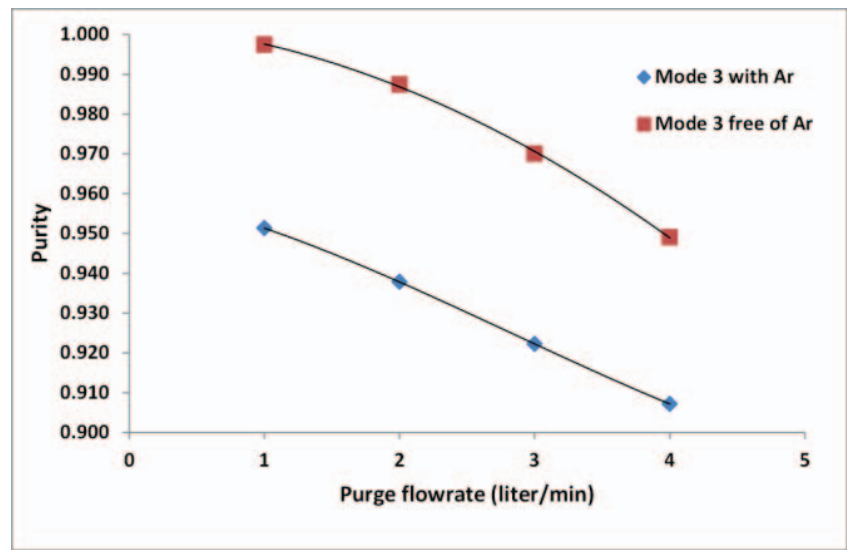

Fig. 3: Effect of argon presence in the feed mixture on the performance of mode 3 of PSA processes.

\subsubsection{Effect of Adsorption Pressure}

Figure 4 shows the effect of adsorption pressure (2-9 bar) on the product purity of 2bed 4-step PSA processes (mode 2), at purge flow rate of 1 liter/min, product flow rate of 1 liter/min, and adsorption time of $40 \mathrm{~s}$. The purity of nitrogen and argon are increased with increasing adsorption pressure, due to increase in the adsorption capacity of the CMS to adsorb more oxygen. The same trend is detected with the argon component. Only oxygen is adsorbed by CMS, therefore the purity of nitrogen in the product could not be higher due to the argon presence in the feed mixture.

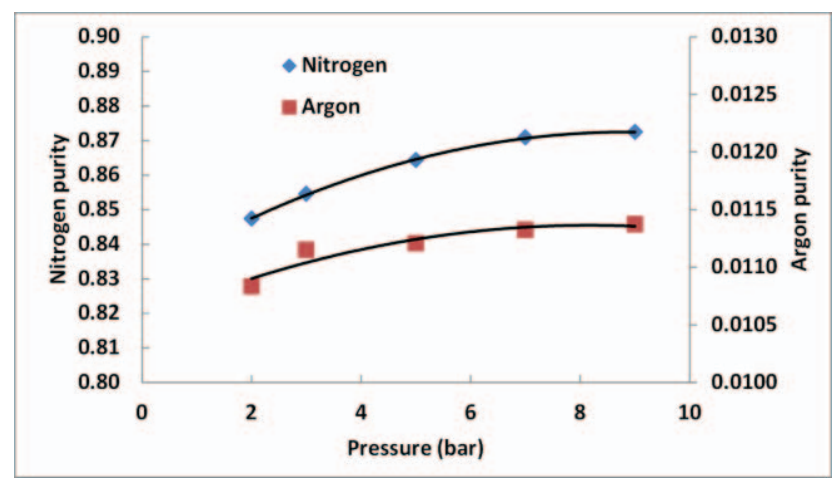

Fig. 4: Effect of adsorption pressure on the purity of the nitrogen and argon in the mode 2 of the PSA process. 


\subsubsection{Effect of Adsorption Time}

Figure 5 shows the effect of adsorption time in the range of 40-250 s with two different feed mixtures, at adsorption pressure of $7 \mathrm{bar}$, purge flow rate of 1 liter/min, and product flow rate of 1 liter/min. Nitrogen purity increased with increasing adsorption time until $100 \mathrm{~s}$ and then decreased slightly or kept stable. Nitrogen separation on CMS is kinetically controlled. Increase in the adsorption time over $100 \mathrm{~s}$ leads to the system approaching an equilibrium state, causing decreases in the nitrogen purity or keeping it stable. At short adsorption time, the time is not enough to adsorb the whole oxygen molecule by CMS. Maximum uptake is obtained at nearly $100 \mathrm{~s}$. Maximum purity $(98 \%)$ is detected by mode 3 without argon presence in the feed mixture, while it dropped to $92 \%$ with argon presence in the feed mixture.

The production of nitrogen purity by mode 3 regardless of feed mixture components binary or ternary is higher than mode 1 . This may be attributed to the effect of the pressure equalization step in mode 3 , which contributed to reducing the axial dispersion effect during the pressurizing step. Moreover, the rapid diffusion of oxygen into the CMS led to the adsorption of oxygen rather than argon and nitrogen, where the diffusion rate constant of oxygen is higher than nitrogen and argon as shown in Table 2. CMS is a kind of adsorbent material with pore sizes in the range of 3-5 $\mathrm{A}^{\mathrm{o}}$, while the diameter of oxygen is $\left(3.46 \mathrm{~A}^{\circ}\right)$, diameter of nitrogen is $\left(3.64 \mathrm{~A}^{\circ}\right)$ and the diameter of argon is $\left(3.43 \mathrm{~A}^{\circ}\right)$. All these reasons lead to kinetic separation of air on CMS. Despite the smaller diameter of argon than other components, low partial pressure of argon in the feed mixture and small diffusion rate constant reduced argon diffusion in the state of the ternaryfeed mixture. This phenomenon was observed by Jee [20] when they used two ternary feed mixtures $\left(\mathrm{O}_{2} / \mathrm{Ar} / \mathrm{N}_{2} ; 95: 4: 1\right.$ and 90:4:6 vol\%) for gas separation on CMS. Nitrogen recovery increased with increasing adsorption time, where the product flow rate increased with increasing the adsorption time. The results are in a good agreement with LaCava [16], Farooq [21], and Mostamand [2].

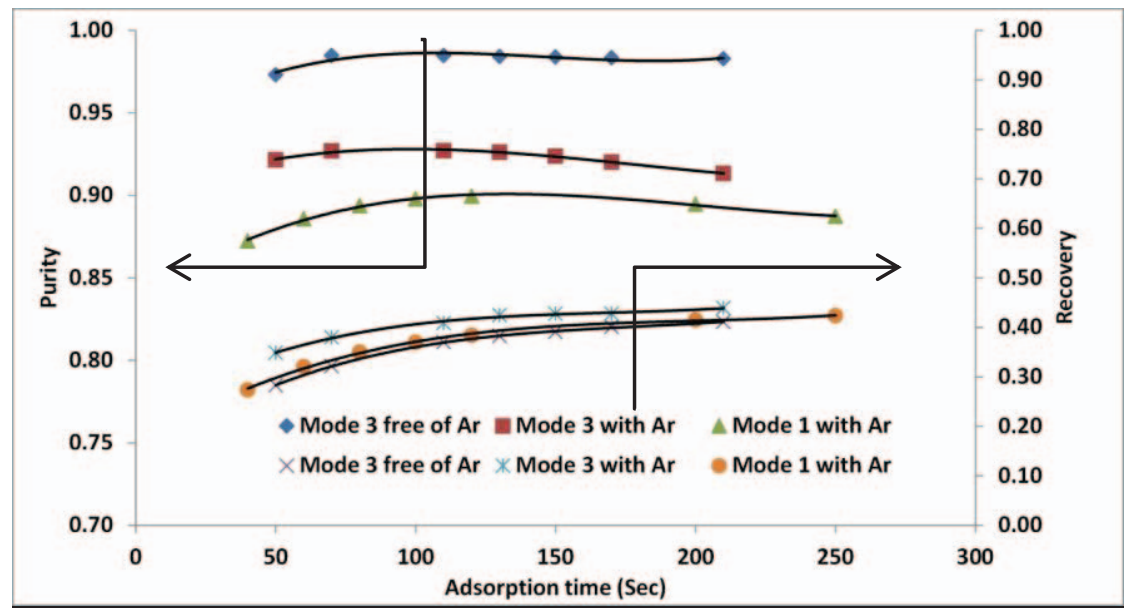

Fig. 5: Effect of the adsorption time on the performance of two modes of PSA process.

\subsubsection{Effect of Purge Flowrate}

Figure 6 shows the effect of purge flow rate for all modes of PSA process on the purity of nitrogen at adsorption time of $80 \mathrm{~s}$, adsorption pressure of $7 \mathrm{bar}$, and product flow rate of 1 liter/min. In all modes, nitrogen purity was approximately kept constant or decreased slightly with increased purge flow rate until 2 liter/min, and it then decreased 
dramatically. The gas used in the purging step is represented as part of the product flow rate during the adsorption step and is enriched with nitrogen. Increasing it over 2 liter $/ \mathrm{min}$ causes an increase in vapor pressure of nitrogen, after displacing oxygen out of the bed and adsorbing it by CMS. So in the next cycle, nitrogen purity will inevitably drop, because most CMS porosity is filled with nitrogen during the purging step. In addition, both the depressurizing step and low purge flowrate $(<1$ liter/min) were enough to expel adsorbed oxygen from CMS porosity. The most out of purge flow rate is observed at low purge flow rate. The results are in agreement with Farooq [21], and Abdel-Rahman [3], and in disagreement with Mostamand [2].

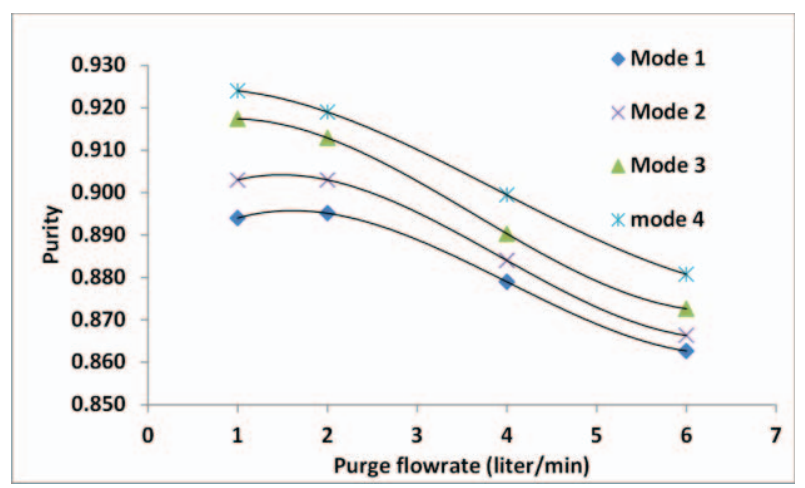

Fig. 6: Effect the purge flow rate on the four modes of the PSA process.

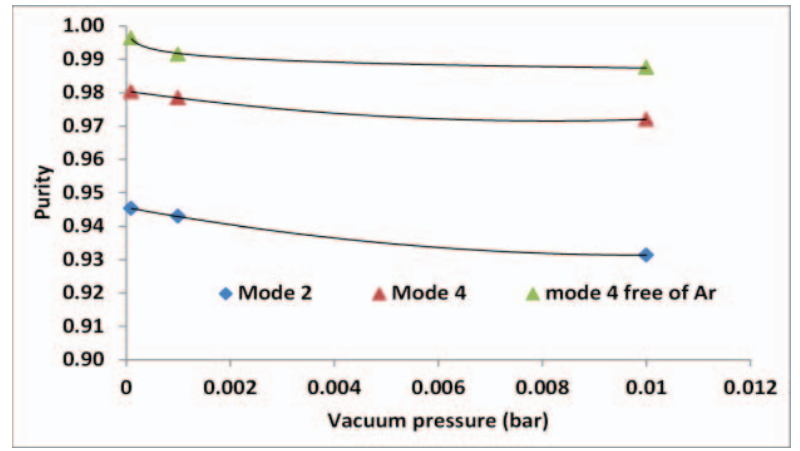

Fig. 7: Effect of vacuum pressure on the performance of two modes of the PSA processes.

\subsubsection{Effect of Vacuum Pressure}

Figure 7 shows the effect of vacuum pressure on the effluent nitrogen purity at adsorption pressure of 7 bar, purge flow rate of 1 liter/min, product flow rate of 0.1 liter/min, and adsorption time of $80 \mathrm{~s}$. All processes have the same trend. High nitrogen purity is detected at a low vacuum pressure $(0.0001$ bar $)$ and then decreased slightly with increasing vacuum pressure. Purging the adsorbent at low vacuum pressure has a significant effect to clean the adsorbent during the purging step. Increases of vacuum pressure lead to sufficient desorption of CMS to prepare it for the next cycle. Maximum purity, over $99 \%$ is observed by mode 4 with the binary feed mixture, while low purity of about $98 \%$ is observed with the same mode (mode 4 ) with the ternary feed mixture. The nitrogen purity produced by mode 4 with a feed mixture that is free of argon is higher than mode 4 with ternary feed mixture and mode 2 . This may be attributed to the faster rate of diffusion of oxygen than nitrogen and argon on CMS, the presence of the pressure equalization step, and the purging step at low vacuum pressure, where they contributed to 
improving the process performance. It is important to consider the argon presence in the feed mixture, and operation steps to design the PSA unit to produce high purity nitrogen from atmospheric air.

\section{CONCLUSIONS}

The mathematical model of single bed adsorber is in good agreement with experimental data. The breakthrough time and amount of nitrogen product are increased slightly with increases in product pressurizing pressure. For the PSA process, high purity of nitrogen was not available when argon was present in the feed mixture. High purity of nitrogen over $99 \%$ was observed by mode 4 when the feed mixture was free of argon, while the purity decreased to $98 \%$ with presence of argon in the feed mixture. Also, the same trend was detected by mode 3, where the purity decreased from $98 \%$ to $92 \%$ when argon was considered in the feed mixture. Only oxygen is adsorbed by CMS from the feed mixture $\left(\mathrm{O}_{2}: 21 \%, \mathrm{~N}_{2}: 78 \%\right.$, Ar: $\left.1 \%\right)$. For different PSA modes, the equalization step in mode 3 , and the equalization step with purging step under vacuum pressure in mode 4 are useful to increase the nitrogen purity to $99 \%$ in comparison with other modes (mode 1 and mode 2) where the nitrogen purity was about $90 \%$. The best arrangement of all modes from higher to lower nitrogen purity is as follows: mode 4, mode 3, mode 2, and mode 1 . For operation parameters, the purities of argon and nitrogen in the product stream increased with increases of adsorption pressure due to increases in adsorption capacity of CMS sieve to adsorb more oxygen. In all modes, the purity of nitrogen increased a few percent between adsorption times of $50-100 \mathrm{~s}$. Also, the purity of nitrogen decreased about $4 \%$ with increases of purge flow rate from 1 to 6 liter $/ \mathrm{min}$, and optimum purge flow rate was between 1 and 2 liter/min.

\section{ACKNOWLEDGEMENT}

The authors would like to thank the Chemical Engineering Department at the University of Tikrit, Iraq for allowing them working in their laboratories.

\section{REFERENCES}

[1] Nicholas AF, Mohd ZH, Zulkarnain Z, Tumirah K. (2019) Activated Carbon for shape stabilized Phase Change Material. Technology and Applications of carbon nanomaterials, 279-308.

[2] Mostamand A, Mofarahi M. (2011) Simulation of a single bed pressure swing adsorption for producing nitrogen. In International Conference on Chemical, Biological and Environment Sciences (ICCEBS'2011) Bangkok.

[3] Abdel-Rahman ZA, Mhdi AH, Auob HS. (2016) Parametric study for nitrogen separation from air by pressure swing adsorption using carbon molecular sieve. Tikrit Journal of Engineering Science. 23 (2), 1-9

[4] Carreon MA. (2018) Molecular sieve membranes for $\mathrm{N}_{2} / \mathrm{CH}_{4}$ separation. Journal of Material Research, 33(1): 32-43.

[5] Lemcoff NO. (1999) Nitrogen separation from air by pressure swing adsorption. Studies in Surface Science and Catalysis. 120: 347-370.

[6] Reid CR, O'koye IP, Thomas KM.( 1998) Adsorption of gases on carbon molecular sieves used for air separation. Spherical Adsorptives as Probes for Kinetic Selectivity. 14(9): 2415-2425. 
[7] Vivo-Vilches JF, Agustín FP, Francisco JM, Francisco C, Christophe S, Ana MR, Alexander F, Alirio ER. (2018) From Carbon Molecular Sieves to VOCs filters: Carbon gels with tailored porosity for hexane isomers adsorption and separation, Microporous and Mesoporous Materials, 270: 161-167.

[8] Shirley AI, Lemcoff NO. (2002) Air separation by carbon molecular sieves. Adsorption. 8: 147-155.

[9] Kim J-D. ( 1995) Production of high-purity nitrogen from air by pressure swing adsorption on zeolite X. Separation Science and Technology, 30: 347-368.

[10] Reynolds SP, Ebner AD, Ritter JA. (2006) Enriching psa cycle for the production of nitrogen from air. Ind. Eng. Chem. Res., 45: 3256-3264.

[11] Yang J, Lee CH. (1998) Adsorption dynamics of a layered bed PSA for $\mathrm{H}_{2}$ recovery from coke oven gas. Aiche Journal, 44: 1325-1334.

[12] Xu M, Wu HC, Lin YS, Deng S. (2018) Simulation and optimization of pressure swing adsorption process for high-temperature air separation by perovskite sorbents. Chemical Engineering Journal, 354: 62-74.

[13] Mate VIA, Dobladez JAD, Alvarez-Torrellas S, Larriba M, Rodriguez AM. (2019) Modeling and simulation of the efficient separation of Methane/Nitrogen mixtures with [Ni3 (HCOO) 6] MOF by PSA. Chemical Engineering Journal, 361: 1007-1018.

[14] Moran A, Talu O. (2018) Limitations of Portable Pressure Swing Adsorption Processes for Air Separation. Industrial \& Engineering Chemistry Research, 57(35): 11981-11987.

[15] Farooq S, Ruthven DM. (1990) A comparison of linear driving force and pore diffusion models for a pressure swing adsorption bulk separation process. Chemical Engineering Science, 45: $107-115$.

[16] LaCava AI, Lemcoff NO. (1996) Single bed pressure swing adsorption process to generate high purity nitrogen. Gas Separation \& purification, 10(2): 113-115.

[17] Makarem MA, Mofarahi M, Jafarian B, Lee CH. (2019) Simulation and analysis of vacuum pressure swing adsorption using the differential quadrature method. Computers \& Chemical Engineering, 121: 483-496.

[18] Vaduva M, Stanciu V. (2006) Separation of nitrogen from air by selective adsorption of carbon molecular sieves. U.P.B. Sci. Bull., 68: 2-10.

[19] Jee JG, Lee J-S, Lee CH. (2001) Air separation by a small-scale two-bed medical $\mathrm{O}_{2}$ pressure swing adsorption. Industrial \& engineering chemistry research, 40: 3647-3658.

[20] Jee JG, Kim MB, Lee CH. (2005) Pressure swing adsorption processes to purify oxygen using a carbon molecular sieve. Chemical Engineering Science, 60: 869 - 882.

[21] Farooq S, Rathor MN, Hidajat K. (1993) A predictive model for a kinetically controlled pressure swing adsorption separation process, Chemical Engineering Science, 48(24): 41294141. 